\title{
Association of preS/S Mutations with Occult Hepatitis B Virus (HBV) Infection in South Korea: Transmission Potential of Distinct Occult HBV Variants
}

\author{
Hong Kim and Bum-Joon Kim *
}

Department of Microbiology and Immunology, Liver Research Institute, Cancer Research Institute and SNUMRC, College of Medicine, Seoul National University, Seoul 110-799, Korea; E-Mail: wild0804@snu.ac.kr

* Author to whom correspondence should be addressed; E-Mail: kbumjoon@snu.ac.kr; Tel.: +82-2-740-8315; Fax: +82-2-743-0881.

Academic Editor: Tatsuo Kanda

Received: 24 February 2015 / Accepted: 8 June 2015 / Published: 15 June 2015

\begin{abstract}
Occult hepatitis B virus infection (HBV) is characterized by HBV DNA positivity but HBV surface antigen (HBsAg) negativity. Occult HBV infection is associated with a risk of HBV transmission through blood transfusion, hemodialysis, and liver transplantation. Furthermore, occult HBV infection contributes to the development of cirrhosis and hepatocellular carcinoma. We recently reported the characteristic molecular features of mutations in the $\mathrm{pre} S / \mathrm{S}$ regions among Korean individuals with occult infections caused by HBV genotype C2; the variants of preS and $S$ related to severe liver diseases among chronically infected patients were also responsible for the majority of HBV occult infections. We also reported that HBsAg variants from occult-infected Korean individuals exhibit lower HBsAg secretion capacity but not reduced HBV DNA levels. In addition, these variants exhibit increased ROS-inducing capacity compared with the wild-type strain, linking HBV occult infections to liver cell damage. Taken together, our previous reports suggest the transmission potential of distinct HBV occult infection-related variants in South Korea.
\end{abstract}

Keywords: hepatitis B virus infection (HBV); occult infection; South Korea; HBV surface antigen (HBsAg); preS/S mutations; genotype C2 


\section{Introduction}

Hepatitis B virus (HBV) infection is a threat to health in many parts of the world, particularly in highly endemic areas, such as the Asia-Pacific region. More than 240 million people are chronic carriers of the virus [1]. HBV infection is associated with a large spectrum of clinical manifestations, ranging from acute or fulminant hepatitis to various forms of chronic infection, including asymptomatic carrier, chronic hepatitis, cirrhosis, and hepatocellular carcinoma (HCC) [2]. The annual number of deaths caused by HBV-related diseases is estimated to be approximately 786,000 worldwide [3]. Because HBV is primarily transmitted vertically from mother to child at birth or during early childhood in highly endemic areas, universal infant vaccination is the most powerful approach to preventing HBV transmission [4-6]. HBV infection is endemic in South Korea; based on the Korean National Health and Nutrition Survey of 2011, the prevalence of hepatitis B virus surface antigen (HBsAg) was 3.4\% among men and $2.6 \%$ among women [7]. HBV vaccination was first introduced to the Korean population in 1983 and dramatically reduced the prevalence of HBsAg-positive chronic carriers from $>10 \%$ to $3.0 \%$ during the approximately thirty-year period that ended in 2011 [7,8]. The immune pressure induced by this successful vaccination likely leads to the generation of diverse mutation patterns that are capable of immune evasion among vaccinated populations. Moreover, the extraordinary prevalence of genotype $\mathrm{C} 2$, which is more virulent than genotype B [1] in this area [9], contributes to the distribution of characteristic HBV mutation patterns related to the progression of liver disease. We have identified several HBV variants related to the progression of liver disease, particularly HCC, among Korean patients [9-24].

\section{Occult Hepatitis B Virus Infection}

Occult HBV infection is defined as the persistence of HBV DNA (primarily in the liver tissue or, in some cases, in the serum) in HBsAg-negative individuals [25-28]. HBV infection is generally diagnosed when the circulating $\mathrm{HBsAg}$ is detected serologically. However, recent progress in molecular-based technologies, such as PCR-based methods, has facilitated the identification of HBV infection in HBsAg-negative individuals with or without circulating antibodies to HBsAg and/or the hepatitis B core antigen (anti-HBc) [29-31]. Several mechanisms have been suggested to explain occult infection, including mutations in HBV genes and particularly HBsAg escape mutations, which cannot be detected by commercial HBsAg assays; host mechanisms that lead to strong suppression of HBV replication and transcription; host immune surveillance; co-infection by other viruses, such as hepatitis $\mathrm{C}$ virus (HCV); and epigenetic mechanisms [32]. Occult HBV infection can be transmitted via blood transfusion and organ transplantation, including liver transplantation. Furthermore, the development of immune-suppressive conditions could lead to the reactivation of occult HBV infection and the progression of acute or fulminant hepatitis. A large body of evidence indicates that occult HBV infection may be significantly associated with severe forms of liver disease, such as cirrhosis and HCC [33,34]. Furthermore, in HCV-infected patients, occult HBV infection can worsen the course of HCV infection [31,35-37]. 


\section{Occult HBV Infections in Korean Subjects}

The reported prevalence of occult HBV infection among the general population in Guangdong, Hainan, and Long An country, China, is 2.0\% (6/294), 3.4\% (68/1995) and 11.5\% (6/52), respectively [38,39]. In Taiwan, the prevalence of occult HBV infection is $7.5 \%(8 / 107)$ in healthy adults, 4\% (9/206) in blood donors, and 10.9\% (5/46) in hepatitis B-vaccinated children [40-42]. The reported prevalence of HBV occult infection among blood donors in Asia is 1:570-1:7517 in China [43,44], 1:3248 in Hong Kong [45], 1:894-1:1029 in Taiwan [46,47] and 1:3832 in Thailand [48].

Several studies of HBV occult infection in South Korea have been conducted. However, the reported prevalence of this infection in the Korean population varies widely from $0.7 \%$ to $16 \%[21,49-51]$. This disparity may be due to differences in methodology, target HBV genomes, and analyzed samples. Notably, a previous report indicated that the prevalence of occult HBV infection is significantly higher among subjects with normal ALT levels in South Korea (31 of 195 subjects, 16\%) [43]. HBV DNA could be detected in 7 of 47 subjects $(15 \%)$, even in sera that were negative for both anti-HBs and IgG anti-HBc. In 18 of 24 nested PCR positive subjects, HBV DNA levels exceeded $10^{5}$ copies $/ \mathrm{mL}$, 10-100 times higher than in Western subjects with occult infection [49].

We previously used a nested PCR protocol to amplify a 1378-bp fragment that included a large hepatitis B surface protein (LHB), including preS1, preS2, and the $S$ region, to demonstrate that the prevalence of HBV occult infections in South Korea was approximately 6.6\% (41/624 individuals) [21]. To evaluate the prevalence of HBeAg-positive results among our occult subjects, we performed HBeAg serology tests with sera available from 21 of 41 occult subjects. Despite being HBsAg seronegative, 15 of 21 subjects (71.4\%) were HBeAg seropositive (Table 1). In particular, one subject (0705-68) exhibited strong $\mathrm{HBeAg}$ seropositivity, even higher than that of the positive control (unpublished observation). Phylogenetic analysis based on sequences of 1125 to $1203 \mathrm{bp}$ demonstrated that all 41 strains associated with occult infections in Korean subjects belonged to genotype C2 [21].

Table 1. Prevalence of occult HBV infection from in Korean subjects, and the distribution of serotype and HBeAg serostatus of occult subjects.

\begin{tabular}{|c|c|c|c|c|}
\hline No. of HBsAg (-) Subjects & \multicolumn{3}{|c|}{ No. of Subjects Positive for Nested PCR } & Prevalence \\
\hline 624 & \multicolumn{3}{|c|}{41} & $6.6 \%$ \\
\hline & \multicolumn{3}{|c|}{ No. of Serotype (41 subjects ${ }^{\text {a }}$ ) } & \\
\hline & $a d r$ & $a d w$ & Untypeable & \\
\hline & $39(95.2 \%)$ & $1(2.4 \%)$ & $1(2.4 \%)$ & \\
\hline & \multicolumn{3}{|c|}{ No. of HBeAg $(+)$ Subjects (21 subjects $\left.{ }^{b}\right)$} & \\
\hline & \multicolumn{3}{|c|}{$15(71.4 \%)$} & \\
\hline
\end{tabular}

a All forty-one subjects with occult HBV infections were proved to have genotype $\mathrm{C} 2$ infections; ${ }^{\mathrm{b}} \mathrm{HBe} \mathrm{Ag}$ serological analysis was performed for 21 of 41 subjects for whom serum samples were available.

We have reported several types of naturally occurring mutations in the preS and $S$ regions that are related to clinical severity in Korean patients with chronic infection. Notably, these mutations are also observed in Korean individuals with occult infections, suggesting that chronically infected patients, particularly patients infected with some HBV variants associated with clinical severity, may be the major 
source of occult HBV infection among HBsAg-negative individuals in South Korea [21]. Herein, we provide a comprehensive review focusing primarily on our previous data on preS and $S$ variants involved in both disease progression among Korean patients with chronic infection [9-20,22-24,52] and occult infections in Korean patients [21,53].

\section{Mutations of the Hepatitis B Virus preS Region Related to Occult Infection in South Korea}

The envelope of HBV is composed of three forms of the HBsAg, which share 226 amino acids at

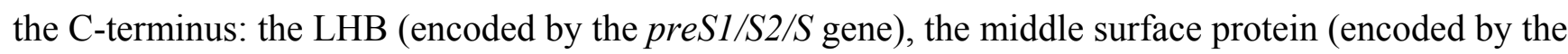
preS $2 / S$ gene), and the HBsAg (encoded by the $S$ gene). At least two essential functions have been attributed to the preS domain during the viral life cycle: attachment to the hepatocyte membrane and budding of the virus in the endoplasmic reticulum (ER) [54,55]. Several lines of evidence indicate that naturally occurring mutations in the preS region correlate with a more progressive form of liver disease [56-58]. Mutations, particularly deletions, in the preS region may affect the ratio between the small and LHBs, resulting in ER stress associated with the aggravation of liver disease [59-61]. Furthermore, the integration of a truncated LHB or middle surface protein into the host chromosome enhances the potential development of HCC by increasing the transactivation capacity [62].

Our previous data indicated that a total of 11 types of mutations in the preS region, including 8 types of mutations in preS1 (i.e., preS1 deletion, W4P/R, K/Q10R, S17A, P32L, W43L/R, H51P, and $\mathrm{I} 84 \mathrm{~T}$ ) and 3 types of mutation in the preS2 region (i.e., preS2 deletion, W3R/Stop and S5A), were detected more frequently in Korean subjects with occult infection than in carriers (Table 2 and [21]). Notably, a high frequency of deletions (22 (53.7\%) of 41 occult subjects) in the preS1 (15 subjects) or preS2 regions (7 subjects) was observed in Korean subjects with occult infections. Interestingly, no subjects had simultaneous deletions in both the preS1 and preS2 regions, suggesting that the simultaneous generation of both deletions in a strain may have a lethal effect on the viral life cycle. Of the 2 types of preS deletions, most preS1 deletions (80\%, 12/15 subjects) were deletions involving the preS1 start codon, leading to an 11-amino acid truncation of LHB, as observed in genotype D [21]. This deletion was first reported as a mutation associated with liver disease progression among Korean patients with chronic infection by our group [15]. Furthermore, we recently demonstrated that chronically infected Korean patients with this type of deletion had a significantly higher HBeAg-positive seroprevalence and higher HBV DNA levels than subjects with wild-type HBV [63]. This finding suggests that deletions involving the preS1 start codon may contribute significantly to disease progression among Korean subjects with chronic HBV infection by extending the duration of HBeAg-seropositive status and increasing HBV replication, which are characteristic traits of highly infective HBV. Thus, together with their high prevalence among Korean subjects with occult infections, the potentially high infectivity of these variants may also contribute to the transmission of occult HBV infection in the Korean population. Notably, one occult-infected subject (0705-68) who exhibited a strongly positive $\mathrm{HBeAg}$ serostatus higher than that of the positive control also exhibited a deletion involving the preS1 start codon (unpublished observations), strongly supporting the above hypothesis. 
Table 2. $P r e S / S$ mutations related to occult infections in South Korea.

\begin{tabular}{|c|c|c|c|c|c|c|}
\hline Regions & Types & Polymerase & Occult $(n=41)$ & Carriers $(n=40)$ & $p$-Value & Clinical Relevance \\
\hline \multirow{9}{*}{ preS1 } & Hepatocyte receptor binding region & - & $29(70.7 \%)$ & $7(17.5 \%)$ & $<0.001$ & {$[58]$} \\
\hline & Start codon deletion & spacer6-12 Deletion & $11(26.8 \%)$ & $3(7.5 \%)$ & $<0.05$ & {$[14,46]$} \\
\hline & $\mathrm{W} 4 \mathrm{P} / \mathrm{R}$ & spacerL9D & $7(17.1 \%)$ & $2(5.0 \%)$ & 0.087 & {$[21,23]$} \\
\hline & K/Q10R & - & $6(14.6 \%)$ & $0(0 \%)$ & $<0.05$ & - \\
\hline & S17A & spacerF22C & $5(12.2 \%)$ & $0(0 \%)$ & $<0.05$ & - \\
\hline & P32L & - & $5(12.2 \%)$ & $0(0 \%)$ & $<0.05$ & - \\
\hline & $\mathrm{W} 43 \mathrm{~L} / \mathrm{R}$ & spacerL48S & $6(14.6 \%)$ & $0(0 \%)$ & $<0.05$ & - \\
\hline & H51P & - & $5(12.2 \%)$ & $1(2.5 \%)$ & 0.096 & - \\
\hline & $\mathrm{I} 84 \mathrm{~T}$ & - & $7(17.1 \%)$ & $0(0 \%)$ & $<0.01$ & - \\
\hline \multirow{4}{*}{ preS2 } & Deletion & spacer132-147 Deletion & $7(17.1 \%)$ & $1(2.5 \%)$ & $<0.05$ & {$[17,44,47]$} \\
\hline & $\mathrm{M} 1 \mathrm{~L} / \mathrm{T} / \mathrm{V}$ & - & $4(9.8 \%)$ & $1(2.5 \%)$ & 0.175 & - \\
\hline & $\mathrm{W} 3 \mathrm{R} / *$ & - & $6(14.6 \%)$ & $0(0 \%)$ & $<0.05$ & - \\
\hline & S5A & - & $5(12.2 \%)$ & $0(0 \%)$ & $<0.05$ & - \\
\hline \multirow{3}{*}{$S$} & "a" determinant & - & $31(75.6 \%)$ & $5(12.5 \%)$ & $<0.001$ & - \\
\hline & $\mathrm{I} / \mathrm{T} 126 \mathrm{~N} / \mathrm{S}$ & - & $11(26.8 \%)$ & $3(7.5 \%)$ & $<0.05$ & - \\
\hline & $\mathrm{W} 182 \mathrm{~L} / *$ & - & 15 & $0(0 \%)$ & $<0.001$ & [19] \\
\hline
\end{tabular}


The previous mutation analysis in Chinese patients with occult infection by HBV genotype C revealed deletions involving the preS1 start codon in 2 of 8 patients $(25.0 \%)$, suggesting that this type of deletion may be common in occult infections in endemic areas of genotype $\mathrm{C}$ infection and is not restricted to South Korea [64].

Our previous molecular epidemiology study using Mbo-II PRA (PCR Restriction Analysis) demonstrated that the preS2 deletion was significantly associated with severe forms of liver disease among chronically infected Korean patients [18]. Furthermore, several lines of evidence suggest that the preS2 deletion correlates with a more progressive form of liver disease by affecting the ratio between HBsAg and LHB, resulting in ER stress associated with the aggravation of liver disease. PreS2 deletions may also contribute to occult infection by shortening the distance between the S promoter and the transcription initiation site of the $S$ mRNA, leading to an altered expression ratio of LHBs to $S$ Ag. This altered ratio can also result in HCC via the up-regulation of the ER stress pathway and increased transactivation capacity $[58,61]$. This finding suggests that overexpression of LHBs among $\mathrm{HBV}$ variants with preS2 deletions may contribute to HBV occult infections by interrupting virion formation. Thus, these results also provide a novel link between occult infection and liver disease progression in genotype $\mathrm{C} 2$ infections with preS2 deletions, particularly among chronically infected Korean patients.

In Chinese patients with genotype $\mathrm{C}$ occult infections, no type of preS2 deletion was detected. Instead, substitutions abolishing the preS2 start codon and introducing a stop signal at the $3 \mathrm{rd}$ codon of preS2 (W3*), which were also observed in Korean subjects, were detected in 2 patients $(25.0 \%, 2 / 8)$ and 1 patient $(12.5 \%, 1 / 8)$, respectively [64]. In addition to the 2 types of preS deletion (i.e., preS1 start codon deletion and preS2 deletion), the $\mathrm{W} 4 \mathrm{P} / \mathrm{R}$ mutation in the preS1 region was identified more frequently in occult subjects than in chronic carriers (occult ( $7 / 41$ subjects) vs. carrier (2/40 carriers); $p=0.087$ ); however, this difference was not statistically significant (Table 2). Our recent real-time PCR-based molecular epidemiology study reported a novel preS1 substitution (W4P/R) that was significantly related to severe liver disease among Korean patients who were chronically infected with genotype C (HCC and liver cirrhosis (12.4\%, 19/153 patients) vs. chronic hepatitis and carrier (1.1\%, $1 / 94$ patients), $p<0.001)$. This mutation changes tryptophan to proline or arginine in the 4 th codon from the preS1 start site. Notably, all W4P/R mutations (20 patients) were detected in male patients, suggesting that the W4P/R mutation occurs predominantly in males [18]. Furthermore, our recent study using stable cell lines and a nude mouse xenograft model demonstrated that LHBs containing the W4P mutation could potentiate tumorigenicity and induce gender disparity in an IL-6-dependent manner. Collectively, the results of our study led us to conclude that W4P/R is related to disease severity in male patients chronically infected with genotype $\mathrm{C} 2$ and may contribute to occult infections in South Korea [24].

Of the 8 types of mutations in preS1 related to occult infections, three (i.e., S17A, P32L and $\mathrm{W} 43 \mathrm{~L} / \mathrm{R})$ are located in the hepatocyte binding site in preS1. Significant differences in the prevalence of mutations in the putative hepatocyte receptor region (17th to 43rd codon) were observed between occult subjects and carriers (occult subjects $(70.7 \%, 29 / 41$ subjects) vs. carrier (17.6\%, 7/40 subjects); $p<0.001$ ), suggesting that defects in hepatocyte binding may be related to occult infection in South Korea [65] (Table 2). 


\section{Mutations in the Hepatitis B Virus $S$ Region Related to Occult Infection in South Korea}

The HBsAg contains a dominant neutralizing epitope termed the "a" determinant in the major hydrophilic region (MHR) of the $S$ gene that spans amino acid positions 100-160. The "a" determinant is widely believed to be located between amino acids 124 and 147 of HBsAg, and mutations in this region are associated with the generation of vaccine escape variants and persistent infection [66-69]. Our previous report revealed two distinct epidemiological traits related to the prevalence of $\mathrm{HBsAg}$ variants among chronically infected Korean patients, including an unexpectedly higher prevalence of naturally occurring MHR variants (47/101, 46.5\%) and a relatively higher mutation frequency (22/59 $(37.3 \%)$ ), as well as the presence of unique mutation patterns in positions outside the "a" determinant region [11]. These factors could influence virological or clinical aspects of HBV infection among chronically infected Korean patients.

Among the MHR mutations related to vaccine escape, the mutation of glycine to arginine in the 145th codon of HBsAg (i.e., G145R) is detected most frequently worldwide [70,71]. However, the G145R mutation was not observed in any of the 41 Korean patients with occult infections in our previous report. Instead, the 126th codon of HBsAg was most frequently affected by MHR mutations in our samples from patients with occult infection (occult subjects $(26.8 \%, 11 / 41$ subjects) vs. carrier (7.5\%, 3/40 subjects); $p=0.037$ ) (Table 2 and [21]). This finding strongly supports our previous report that MHR mutations of the I/T126N/S type are most prevalent among chronically infected Korean patients with genotype C2 infections [11]. A T126I mutation specific to genotype C was also previously associated with poorer clinical outcomes in patients infected with genotype $\mathrm{C}$, possibly via a change in HBsAg antigenicity [72].

Notably, including the sW182L and sW182* mutations which have amino acid substitutions from tryptophan (W) to Stop and leucine (L) at the 182th codon of HBsAg, respectively, the 182th codon is the codon most frequently affected in mutations of HBsAg in occult-infected subjects (occult subjects $(36.6 \%, 15 / 41$ subjects) $v s$. carrier $(0 \%, 0 / 40$ subjects); $p<0.001)$ (Table 2$)$. In particular, sW182L was distinctly present in only patients with occult infection and was not observed in chronically infected Korean patients [21]. We previously introduced a novel mutation type outside the MHR regions (i.e., sW182*) that resulted in a premature stop at codon 182 in the HBsAg gene of genotype C2 [20]. Our molecular epidemiology study employing multi-probe real-time PCR demonstrated that the prevalence of this mutation was significantly higher in patients with progressive forms of the disease (i.e., HCC and liver cirrhosis) than in patients with less severe forms of the disease (i.e., chronic hepatitis and carrier) (31.8\% (56/176 patients) vs. $17.2 \%$ (17/99 patients); $p=0.010)$. Furthermore, an in vitro study employing stable cell lines expressing HBsAg containing sW182* also strongly supported the relationship of this mutation with HCC [20]. Interestingly, the predominance of sW182* in Korean occult-infected subjects suggests that transfer from chronically infected patients to HBsAg-negative individuals may occur in the Korean population, leading to occult infections (Figure 1). The HBV DNA levels of patients infected with sW182* variants were significantly lower than those infected with wild-type strains, suggesting that these variants may employ mechanisms that reduce the DNA level [20]. The truncated $S$ protein may interrupt the formation of normal virions, leading to a loss of infectivity and reduced DNA levels. Consistent with this hypothesis, a study that employed full HBV genomic DNA harboring the $\mathrm{sW} 182 *$ mutation demonstrated that this variant 
failed to form normal HBV virions [20]. This finding also provides a likely explanation for the prevalence of this variant in subjects with occult HBV infection and in patients with severe types of liver diseases.

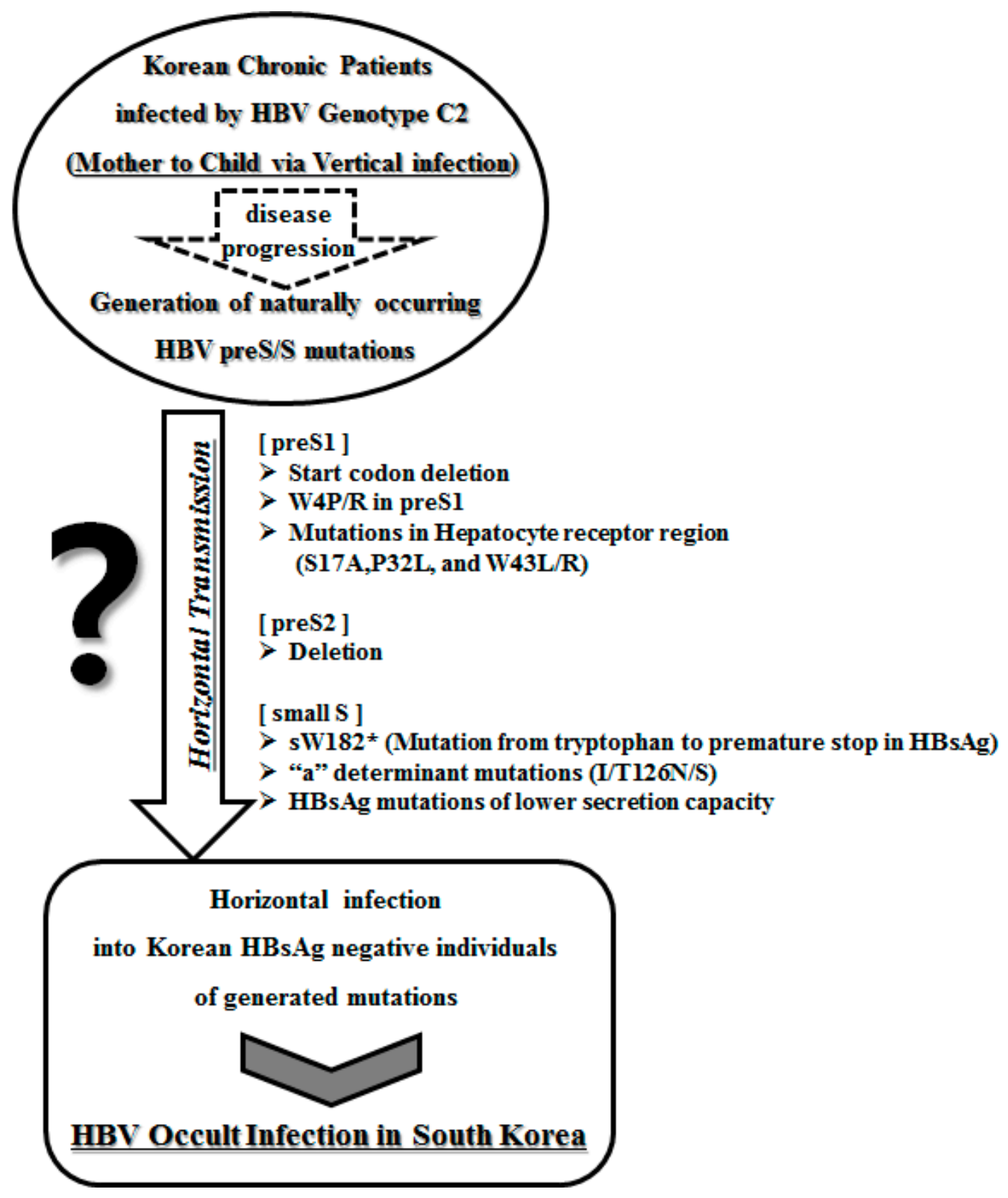

Figure 1. Transmission potential of distinct HBV occult infection-related variants in South Korea.

In Chinese patients with genotype C occult infections, the G145R mutation was not detected. In 6 of 8 patients (75\%), MHR mutations were detected. Stop codon mutations leading to truncated HBsAg, including the sW182* mutation, were also detected in 3 of 8 patients $(37.5 \%)$ [64].

A specific type of naturally occurring HBsAg mutation may lead to reduced HBsAg secretion [73]. One of the major mechanisms leading to HBV occult infections is the reduction of circulating HBsAg levels [64,74-76]. Consistent with these findings, our recent transient transfection study that employed 10 uncommon HBsAg variants from occult-infected Korean subjects also suggested that a major mechanism of occult infection may involve defects in HBsAg secretion rather than alterations in 
HBsAg antigenicity. However, most of the variants (9/10 variants) exhibited normal virion secretion capacity that was comparable to or higher than that of wild-type virus [53]. This finding provides novel insight into the intrinsic nature of HBV occult infection, which leads to both HBsAg-seronegative status and horizontal infectivity. Furthermore, most of the variants generated more reactive oxidative species than the wild-type virus, increasing the potential for transmission from chronically ill Korean patients, particularly those with severe liver diseases, to the HBsAg-negative Korean population. Although the HBsAg mutations observed in Korean occult-infected subjects were typically associated with reduced levels of secreted HBsAg in comparison to the wild-type virus, as indicated by ELISA, significant differences in the level of secreted HBsAg were observed between variants with different mutation patterns. In particular, specific mutations outside of the "a" determinant (i.e., sW172R and the sW182* and sW182L mutations in the 182th codon) nearly abrogated the secretion of HBsAg, despite being single-point mutations. This finding suggests that these codons may be very important for HBsAg secretion [53]. Considering our recent report implicating the reduced secretion of HBsAg by an occult infection-related variant in the induction of the ER stress pathway [77], HBsAg secretion deficiency caused by the accumulation of occult infection-related HBsAg mutations may represent a link between occult infection and the progression of liver disease.

How the variants associated with apparent HBsAg positive infection in chronic patients lead to HBsAg seronegative infections in occult infection cases remains to be addressed. However, it is tempting to speculate that a difference in the HBV type mediating transmission between chronic infection and occult infection plays a role. As demonstrated in our previous reports, in chronic infection, infection by wild-type HBV rather than by variants may be predominant. Variants could be generated from wild-type via host immune pressure. Therefore, the coexistence of both wild-type and variant HBV may maintain the HBsAg seropositive phase in chronic infection. However, in occult infection, infection by distinct variants may be predominant. Therefore, exclusive infection by variants in the absence of wild-type HBV may be primarily responsible for the HBsAg-seronegative phase in occult infection.

\section{Conclusions}

In conclusion, our previous reports suggest that a deficiency in the HBsAg secretion capacity induced by specific mutations in the preS and $S$ regions or defects in virion secretion caused by pre $S$ deletions may play a pivotal role in occult infections with HBV genotype $\mathrm{C} 2$ in the South Korean population. Furthermore, the possible accumulation of HBsAg or HBV virions in the ER in the presence of mutations may represent a link between occult infection and liver disease progression. The association of distinct types of variants in the $\mathrm{preS} / \mathrm{S}$ region, such as $\mathrm{preS} 1$ start codon deletion, preS2 deletion, W4P/R, and sW182*, with clinical severity among chronically infected Korean patients may suggest that these variants are also responsible for the majority of occult infections in South Korea (Figure 1). The possibility of transmission of these variants between Korean populations via organ transplantation or transfusion from donors with occult infections cannot also be excluded. 


\section{Acknowledgments}

This review was supported by a National Research Foundation (NRF) of Korea grant funded by the Korean government (Ministry of Education, Science, and Technology, MEST, No. 2013-005810).

\section{Author Contributions}

Bum-Joon Kim conceptualized this review and wrote the manuscript; Hong Kim prepared the figure and wrote the manuscript.

\section{Conflicts of Interest}

The authors declare no conflict of interest.

\section{References}

1. Orito, E.; Mizokami, M.; Sakugawa, H.; Michitaka, K.; Ishikawa, K.; Ichida, T.; Okanoue, T.; Yotsuyanagi, H.; Iino, S. A case-control study for clinical and molecular biological differences between hepatitis B viruses of genotypes B and C. Hepatology 2001, 33, 218-223.

2. Kao, J.H.; Chen, D.S. Global control of hepatitis B virus infection. Lancet Infect. Dis. 2002, 2, 395-403.

3. Lozano, R.; Naghavi, M.; Foreman, K.; Lim, S.; Shibuya, K.; Aboyans, V.; Abraham, J.; Adair, T.; Aggarwal, R.; Ahn, S.Y.; et al. Global and regional mortality from 235 causes of death for 20 age groups in 1990 and 2010: A systematic analysis for the Global Burden of Disease Study 2010. Lancet 2012, 380, 2095-2128.

4. Ganem, D.; Prince, A.M. Hepatitis B virus infection-Natural history and clinical consequences. N. Engl. J. Med. 2004, 350, 1118-1129.

5. Wong, V.C.; Ip, H.M.; Reesink, H.W.; Lelie, P.N.; Reerink-Brongers, E.E.; Yeung, C.Y.; Ma, H.K. Prevention of the HBsAg carrier state in newborn infants of mothers who are chronic carriers of HBsAg and $\mathrm{HBeAg}$ by administration of hepatitis-B vaccine and hepatitis-B immunoglobulin. Double-blind randomised placebo-controlled study. Lancet 1984, 1, 921-926.

6. De la Hoz, F.; Perez, L.; de Neira, M.; Hall, A.J. Eight years of hepatitis B vaccination in Colombia with a recombinant vaccine: Factors influencing hepatitis B virus infection and effectiveness. Int. J. Infect. Dis. 2008, 12, 183-189.

7. Prevention, K.C. Korea national health and nutrition examination survey. Int. J. Epidemiol. 2011, 43, 69-77.

8. Chun, B.Y.; Lee, M.K.; Rho, Y.K. The prevalence of hepatitis B surface antigen among Korean by literature review. Korean J. Epidemiol. 1992, 14, 54-62.

9. Kim, H.; Jee, Y.M.; Song, B.C.; Shin, J.W.; Yang, S.H.; Mun, H.S.; Kim, H.J.; Oh, E.J.; Yoon, J.H.; Kim, Y.J.; et al. Molecular epidemiology of hepatitis B virus (HBV) genotypes and serotypes in patients with chronic HBV infection in Korea. Intervirology 2007, 50, 52-57.

10. Song, B.C.; Kim, H.; Kim, S.H.; Cha, C.Y.; Kook, Y.H.; Kim, B.J. Comparison of full length sequences of hepatitis B virus isolates in hepatocellular carcinoma patients and asymptomatic carriers of Korea. J. Med. Virol. 2005, 75, 13-19. 
11. Song, B.C.; Kim, S.H.; Kim, H.; Ying, Y.H.; Kim, H.J.; Kim, Y.J.; Yoon, J.H.; Lee, H.S.; Cha, C.Y.; Kook, Y.H.; et al. Prevalence of naturally occurring surface antigen variants of hepatitis B virus in Korean patients infected chronically. J. Med. Virol. 2005, 76, 194-202.

12. Kim, H.; Jee, Y.; Mun, H.S.; Park, J.H.; Yoon, J.H.; Kim, Y.J.; Lee, H.S.; Hyun, J.W.; Hwang, E.S.; Cha, C.Y.; et al. Characterization of two hepatitis B virus populations in a single Korean hepatocellular carcinoma patient with an HBeAg-negative serostatus: A novel X-Gene-deleted strain with inverted duplication sequences of upstream enhancer site II. Intervirology 2007, 50, 273-280.

13. Kim, H.; Jee, Y.; Mun, H.S.; Song, B.C.; Park, J.H.; Hyun, J.W.; Hwang, E.S.; Cha, C.Y.; Kook, Y.H.; Kim, B.J. Comparison of full genome sequences between two hepatitis B virus strains with or without preC mutation (A1896) from a single Korean hepatocellular carcinoma patient. J. Microb. Biotechnol. 2007, 17, 701-704.

14. Kim, H.J.; Park, J.H.; Jee, Y.; Lee, S.A.; Kim, H.; Song, B.C.; Yang, S.; Lee, M.; Yoon, J.H.; Kim, Y.J.; et al. Hepatitis B virus X mutations occurring naturally associated with clinical severity of liver disease among Korean patients with chronic genotype C infection. J. Med. Virol. 2008, 80, 1337-1343.

15. Mun, H.S.; Lee, S.A.; Jee, Y.; Kim, H.; Park, J.H.; Song, B.C.; Yoon, J.H.; Kim, Y.J.; Lee, H.S.; Hyun, J.W.; et al. The prevalence of hepatitis B virus preS deletions occurring naturally in Korean patients infected chronically with genotype C. J. Med. Virol. 2008, 80, 1189-1194.

16. Lee, S.A.; Cho, Y.K.; Lee, K.H.; Hwang, E.S.; Kook, Y.H.; Kim, B.J. Gender disparity in distribution of the major hydrophilic region variants of hepatitis B virus genotype $\mathrm{C}$ according to hepatitis B e antigen serostatus. J. Med. Virol. 2011, 83, 405-411.

17. Lee, S.A.; Mun, H.S.; Kim, H.; Lee, H.K.; Kim, B.J.; Hwang, E.S.; Kook, Y.H.; Kim, B.J. Naturally occurring hepatitis B virus X deletions and insertions among Korean chronic patients. J. Med. Virol. 2011, 83, 65-70.

18. Mun, H.S.; Lee, S.A.; Kim, H.; Hwang, E.S.; Kook, Y.H.; Kim, B.J. Novel F141L pre-S2 mutation in hepatitis $\mathrm{B}$ virus increases the risk of hepatocellular carcinoma in patients with chronic genotype C infections. J. Virol. 2011, 85, 123-132.

19. Kim, D.W.; Lee, S.A.; Hwang, E.S.; Kook, Y.H.; Kim, B.J. Naturally occurring precore/core region mutations of hepatitis $\mathrm{B}$ virus genotype $\mathrm{C}$ related to hepatocellular carcinoma. PLoS ONE 2012, 7, e47372.

20. Lee, S.A.; Kim, K.; Kim, H.; Kim, B.J. Nucleotide change of codon 182 in the surface gene of hepatitis $\mathrm{B}$ virus genotype $\mathrm{C}$ leading to truncated surface protein is associated with progression of liver diseases. J. Hepatol. 2012, 56, 63-69.

21. Kim, H.; Lee, S.A.; Kim, D.W.; Lee, S.H.; Kim, B.J. Naturally occurring mutations in large surface genes related to occult infection of hepatitis B virus genotype C. PLoS ONE 2013, 8, e54486.

22. Lee, S.A.; Kim, K.J.; Kim, D.W.; Kim, B.J. Male-specific W4P/R mutation in the pre-S1 region of hepatitis $\mathrm{B}$ virus, increasing the risk of progression of liver diseases in chronic patients. J. Clin. Microbiol. 2013, 51, 3928-3936.

23. Kim, B.J. Hepatitis B virus mutations related to liver disease progression of Korean patients. World J. Gastroenterol. 2014, 20, 460-467. 
24. Lee, S.A.; Kim, H.; Won, Y.S.; Seok, S.H.; Na, Y.; Shin, H.B.; Inn, K.S.; Kim, B.J. Male-specific hepatitis B virus large surface protein variant W4P potentiates tumorigenicity and induces gender disparity. Mol. Cancer 2015, 14, doi:10.1186/s12943-015-0303-7.

25. Raimondo, G.; Balsano, C.; Craxi, A.; Farinati, F.; Levrero, M.; Mondelli, M.; Pollicino, T.; Squadrito, G.; Tiribelli, C. Occult hepatitis B virus infection. Dig. Liver Dis. 2000, 32, 822-826.

26. Torbenson, M.; Thomas, D.L. Occult hepatitis B. Lancet Infect. Dis. 2002, 2, 479-486.

27. Conjeevaram, H.S.; Lok, A.S. Occult hepatitis B virus infection: A hidden menace? Hepatology 2001, 34, 204-206.

28. Raimondo, G.; Allain, J.P.; Brunetto, M.R.; Buendia, M.A.; Chen, D.S.; Colombo, M.; Craxi, A.; Donato, F.; Ferrari, C.; Gaeta, G.B.; et al. Statements from the Taormina expert meeting on occult hepatitis B virus infection. J. Hepatol. 2008, 49, 652-657.

29. Zhang, Y.Y.; Hansson, B.G.; Kuo, L.S.; Widell, A.; Nordenfelt, E. Hepatitis B virus DNA in serum and liver is commonly found in Chinese patients with chronic liver disease despite the presence of antibodies to HBsAg. Hepatology 1993, 17, 538-544.

30. Liang, T.J.; Baruch, Y.; Ben-Porath, E.; Enat, R.; Bassan, L.; Brown, N.V.; Rimon, N.; Blum, H.E.; Wands, J.R. Hepatitis B virus infection in patients with idiopathic liver disease. Hepatology 1991, 13, 1044-1051.

31. Koike, K.; Kobayashi, M.; Gondo, M.; Hayashi, I.; Osuga, T.; Takada, S. Hepatitis B virus DNA is frequently found in liver biopsy samples from hepatitis $\mathrm{C}$ virus-infected chronic hepatitis patients. J. Med. Virol. 1998, 54, 249-255.

32. Bréchot, C.; Hadchouel, M.; Scotto, J.; Fonck, M.; Potet, F.; Vyas, G.N.; Tiollais, P. State of hepatitis B virus DNA in hepatocytes of patients with hepatitis B surface antigen-positive and -negative liver diseases. Proc. Natl. Acad. Sci. USA 1981, 78, 3906-3910.

33. Samal, J.; Kandpal, M.; Vivekanandan, P. Molecular mechanisms underlying occult hepatitis B virus infection. Clin. Microbiol. Rev. 2012, 25, 142-163.

34. Shafritz, D.A.; Shouval, D.; Sherman, H.I.; Hadziyannis, S.J.; Kew, M.C. Integration of hepatitis $\mathrm{B}$ virus DNA into the genome of liver cells in chronic liver disease and hepatocellular carcinoma. Studies in percutaneous liver biopsies and post-mortem tissue specimens. N. Engl. J. Med. 1981, 305, 1067-1073.

35. De Maria, N.; Colantoni, A.; Friedlander, L.; Leandro, G.; Idilman, R.; Harig, J.; van Thiel, D.H. The impact of previous HBV infection on the course of chronic hepatitis C. Am. J. Gastroenterol. 2000, 95, 3529-3536.

36. Sagnelli, E.; Coppola, N.; Scolastico, C.; Mogavero, A.R.; Filippini, P.; Piccinino, F. HCV genotype and "silent" HBV coinfection: Two main risk factors for a more severe liver disease. J. Med. Virol. 2001, 64, 350-355.

37. Chemin, I.; Zoulim, F.; Merle, P.; Arkhis, A.; Chevallier, M.; Kay, A.; Cova, L.; Chevallier, P.; Mandrand, B.; Trépo, C. High incidence of hepatitis B infections among chronic hepatitis cases of unknown aetiology. J. Hepatol. 2001, 34, 447-454.

38. Fang, Z.L.; Zhuang, H.; Wang, X.Y.; Ge, X.M.; Harrison, T.J. Hepatitis B virus genotypes, phylogeny and occult infection in a region with a high incidence of hepatocellular carcinoma in China. World J. Gastroenterol. 2004, 10, 3264-3268. 
39. Luo, K.X.; Zhou, R.; He, C.; Liang, Z.S.; Jiang, S.B. Hepatitis B virus DNA in sera of virus carriers positive exclusively for antibodies to the hepatitis B core antigen. J. Med. Virol. 1991, 35, 55-59.

40. Shih, L.N.; Sheu, J.C.; Wang, J.T.; Huang, G.T.; Yang, P.M.; Lee, H.S.; Sung, J.L.; Wang, T.H.; Chen, D.S. Serum hepatitis B virus DNA in healthy HBsAg-negative Chinese adults evaluated by polymerase chain reaction. J. Med. Virol. 1990, 32, 257-260.

41. Wang, J.T.; Wang, T.H.; Sheu, J.C.; Shih, L.N.; Lin, J.T.; Chen, D.S. Detection of hepatitis B virus DNA by polymerase chain reaction in plasma of volunteer blood donors negative for hepatitis B surface antigen. J. Infect. Dis. 1991, 163, 397-399.

42. Mu, S.C.; Lin, Y.M.; Jow, G.M.; Chen, B.F. Occult hepatitis B virus infection in hepatitis B vaccinated children in Taiwan. J. Hepatol. 2009, 50, 264-272.

43. Zheng, X.; Ye, X.; Zhang, L.; Wang, W.; Shuai, L.; Wang, A.; Zeng, J.; Candotti, D.; Allain, J.P.; $\mathrm{Li}, \mathrm{C}$. Characterization of occult hepatitis B virus infection from blood donors in China. J. Clin. Microbiol. 2011, 49, 1730-1737.

44. Yuan, Q.; Ou, S.H.; Chen, C.R.; Ge, S.X.; Pei, B.; Chen, Q.R.; Yan, Q.; Lin, Y.C.; Ni, H.Y.; Huang, C.H.; et al. Molecular characteristics of occult hepatitis B virus from blood donors in southeast China. J. Clin. Microbiol. 2010, 48, 357-362.

45. Yuen, M.F.; Wong, D.K.; Lee, C.K.; Tanaka, Y.; Allain, J.P.; Fung, J.; Leung, J.; Lin, C.K.; Sugiyama, M.; Sugauchi, F.; et al. Transmissibility of hepatitis B virus (HBV) infection through blood transfusion from blood donors with occult HBV infection. Clin. Infect. Dis. 2011, 52, 624-632.

46. Yang, M.H.; Li, L.; Hung, Y.S.; Hung, C.S.; Allain, J.P.; Lin, K.S.; Tsai, S.J. The efficacy of individual-donation and minipool testing to detect low-level hepatitis B virus DNA in Taiwan. Transfusion 2010, 50, 65-74.

47. Li, L.; Chen, P.J.; Chen, M.H.; Chak, K.F.; Lin, K.S.; Tsai, S.J. A pilot study for screening blood donors in Taiwan by nucleic acid amplification technology: Detecting occult hepatitis B virus infections and closing the serologic window period for hepatitis $\mathrm{C}$ virus. Transfusion 2008, 48 , 1198-1206.

48. Phikulsod, S.; Oota, S.; Tirawatnapong, T.; Sakuldamrongpanich, T.; Chalermchan, W.; Louisirirotchanakul, S.; Tanprasert, S.; Chongkolwatana, V.; Kitpoka, P.; Phanuphak, P.; et al. One-year experience of nucleic acid technology testing for human immunodeficiency virus Type 1, hepatitis C virus, and hepatitis B virus in Thai blood donations. Transfusion 2009, 49, 1126-1135.

49. Kim, S.M.; Lee, K.S.; Park, C.J.; Lee, J.Y.; Kim, K.H.; Park, J.Y.; Lee, J.H.; Kim, H.Y.; Yoo, J.Y.; Jang, M.K. Prevalence of occult HBV infection among subjects with normal serum ALT levels in Korea. J. Infect. 2007, 54, 185-191.

50. Song, E.Y.; Yun, Y.M.; Park, M.H.; Seo, D.H. Prevalence of occult hepatitis B virus infection in a general adult population in Korea. Intervirology 2009, 52, 57-62.

51. Kang, S.Y.; Kim, M.H.; Lee, W.I. The prevalence of "anti-HBc alone" and HBV DNA detection among anti-HBc alone in Korea. J. Med. Virol. 2010, 82, 1508-1514.

52. Lee, H.; Kim, H.; Lee, S.A.; Won, Y.S.; Kim, H.I.; Inn, K.S.; Kim, B.J. Upregulation of endoplasmic reticulum stress and reactive oxygen species by naturally occurring mutations in HBcAg of the hepatitis B virus. J. Gen. Virol. 2015, doi:10.1099/vir.0.000134. 
53. Kim, H.; Lee, S.A.; Won, Y.S.; Lee, H.; Kim, B.J. Occult infection related hepatitis B surface antigen variants showing lowered secretion capacity. World J. Gastroenterol. 2015, 21, 1794-1803.

54. Klingmüller, U.; Schaller, H. Hepadnavirus infection requires interaction between the viral pre-S domain and a specific hepatocellular receptor. J. Virol. 1993, 67, 7414-7422.

55. Dyson, M.R.; Murray, K. Selection of peptide inhibitors of interactions involved in complex protein assemblies: Association of the core and surface antigens of hepatitis B virus. Proc. Natl. Acad. Sci. USA 1995, 92, 2194-2198.

56. Trautwein, C.; Schrem, H.; Tillmann, H.L.; Kubicka, S.; Walker, D.; Böker, K.H.; Maschek, H.J.; Pichlmayr, R.; Manns, M.P. Hepatitis B virus mutations in the pre-S genome before and after liver transplantatio. Hepatology 1996, 24, 482-488.

57. Bock, C.T.; Tillmann, H.L.; Maschek, H.J.; Manns, M.P.; Trautwein, C. A preS mutation isolated from a patient with chronic hepatitis B infection leads to virus retention and misassembly. Gastroenterology 1997, 113, 1976-1982.

58. Hsieh, Y.-H.; Su, I.-J.; Wang, H.-C.; Chang, W.-W.; Lei, H.-Y.; Lai, M.-D.; Chang, W.-T.; Huang, W. Pre-S mutant surface antigens in chronic hepatitis B virus infection induce oxidative stress and DNA damage. Carcinogenesis 2004, 25, 2023-2032.

59. Hung, J.H.; Su, I.J.; Lei, H.Y.; Wang, H.C.; Lin, W.C.; Chang, W.T.; Huang, W.; Chang, W.C.; Chang, Y.S.; Chen, C.C.; et al. Endoplasmic reticulum stress stimulates the expression of cyclooxygenase-2 through activation of NF-kB and pp38 mitogen-activated protein kinase. J. Biol. Chem. 2004, 279, 46384-46392.

60. Wang, H.C.; Wu, H.C.; Chen, C.F.; Fausto, N.; Lei, H.Y.; Su, I.J. Different types of ground glass hepatocytes in chronic hepatitis B virus infection contain specific pre-S mutants that may induce endoplasmic reticulum stress. Am. J. Pathol. 2003, 163, 2441-2449.

61. Wang, H.-C.; Huang, W.; Lai, M.-D.; Su, I.-J. Hepatitis B virus pre-S mutants, endoplasmic reticulum stress and hepatocarcinogenesis. Cancer Sci. 2006, 97, 683-688.

62. Caselmann, W.H.; Meyer, M.; Kekule, A.S.; Lauer, U.; Hofschneider, P.H.; Koshy, R. A trans-activator function is generated by integration of hepatitis B virus preS/S sequences in human hepatocellular carcinoma DNA. Proc. Natl. Acad. Sci. USA 1990, 87, 2970-2974.

63. Lee, S.A.; Ki, K.J.; Kim, H.; Choi, W.H.; Won, Y.S.; Kim, B.J. Hepatitis B virus preS1 deletion is related to viral replication increase and disease progression. World J. Gastroenterol. 2015, in press.

64. Fang, Y.; Teng, X.; Xu, W.Z.; Li, D.; Zhao, H.W.; Fu, L.J.; Zhang, F.M.; Gu, H.X. Molecular characterization and functional analysis of occult hepatitis B virus infection in Chinese patients infected with genotype C. J. Med. Virol. 2009, 81, 826-835.

65. Yan, H.; Peng, B.; He, W.; Zhong, G.; Qi, Y.; Ren, B.; Gao, Z.; Jing, Z.; Song, M.; Xu, G.; et al. Molecular determinants of hepatitis B and D virus entry restriction in mouse sodium taurocholate cotransporting polypeptide. J. Virol. 2013, 87, 7977-7991.

66. Lada, O.; Benhamou, Y.; Poynard, T.; Thibault, V. Coexistence of hepatitis B surface antigen (HBsAg) and anti-HBs antibodies in chronic hepatitis B virus carriers: Influence of "a" determinant variants. J. Virol. 2006, 80, 2968-2975. 
67. Banerjee, A.; Chandra, P.K.; Datta, S.; Biswas, A.; Bhattacharya, P.; Chakraborty, S.; Chakrabarti, S.; Bhattacharya, S.K.; Chakravarty, R. Frequency and significance of hepatitis B virus surface gene variant circulating among "antiHBc only" individuals in Eastern India. J. Clin. Virol. 2007, 40, 312-317.

68. Amini-Bavil-Olyaee, S.; Vucur, M.; Luedde, T.; Trautwein, C.; Tacke, F. Differential impact of immune escape mutations G145R and P120T on the replication of lamivudine-resistant hepatitis B virus e antigen-positive and -negative strains. J. Virol. 2010, 84, 1026-1033.

69. Zuckerman, A.J. Effect of hepatitis B virus mutants on efficacy of vaccination. Lancet 2000, 355, 1382-1384.

70. Cooreman, M.P.; van Roosmalen, M.H.; te Morsche, R.; Sunnen, C.M.; de Ven, E.M.; Jansen, J.B.; Tytgat, G.N.; de Wit, P.L.; Paulij, W.P. Characterization of the reactivity pattern of murine monoclonal antibodies against wild-type hepatitis B surface antigen to G145R and other naturally occurring "a" loop escape mutations. Hepatology 1999, 30, 1287-1292.

71. Oon, C.J.; Chen, W.N.; Goo, K.S.; Goh, K.T. Intra-familial evidence of horizontal transmission of hepatitis B virus surface antigen mutant G145R. J. Infect. 2000, 41, 260-264.

72. Ren, F.; Tsubota, A.; Hirokawa, T.; Kumada, H.; Yang, Z.; Tanaka, H. A unique amino acid substitution, T126I, in human genotype $\mathrm{C}$ of hepatitis $\mathrm{B}$ virus $\mathrm{S}$ gene and its possible influence on antigenic structural change. Gene 2006, 383, 43-51.

73. Chua, P.K.; Wang, R.Y.; Lin, M.H.; Masuda, T.; Suk, F.M.; Shih, C. Reduced secretion of virions and hepatitis B virus (HBV) surface antigen of a naturally occurring HBV variant correlates with the accumulation of the small $\mathrm{S}$ envelope protein in the endoplasmic reticulum and Golgi apparatus. J. Virol. 2005, 79, 13483-13496.

74. Jeantet, D.; Chemin, I.; Mandrand, B.; Tran, A.; Zoulim, F.; Merle, P.; Trepo, C.; Kay, A. Cloning and expression of surface antigens from occult chronic hepatitis B virus infections and their recognition by commercial detection assays. J. Med. Virol. 2004, 73, 508-515.

75. Chaudhuri, V.; Tayal, R.; Nayak, B.; Acharya, S.K.; Panda, S.K. Occult hepatitis B virus infection in chronic liver disease: Full-length genome and analysis of mutant surface promoter. Gastroenterology 2004, 127, 1356-1371.

76. Sengupta, S.; Rehman, S.; Durgapal, H.; Acharya, S.K.; Panda, S.K. Role of surface promoter mutations in hepatitis B surface antigen production and secretion in occult hepatitis B virus infection. J. Med. Virol. 2007, 79, 220-228.

77. Lee, I.K.; Kim, H.; Won, Y.S.; Kim, B.J. Induction of ER-derived oxidative stress by an occult infection related S surface antigen variant. World J. Gastroenterol. 2015, in press.

(C) 2015 by the authors; licensee MDPI, Basel, Switzerland. This article is an open access article distributed under the terms and conditions of the Creative Commons Attribution license (http://creativecommons.org/licenses/by/4.0/). 